\title{
Mutations in HAMP and HJV genes and their impact on expression of clinical hemochromatosis in a cohort of 100 Spanish patients homozygous for the $\mathrm{C282}$ Y mutation of HFE gene
}

\author{
Albert Altès • Vanessa Bach • Angels Ruiz • \\ Anna Esteve • Jordi Felez • Angel F. Remacha • \\ M. Pilar Sardà $\cdot$ Montserrat Baiget
}

Received: 10 December 2008 / Accepted: 25 January 2009/Published online: 13 February 2009

(C) Springer-Verlag 2009

\begin{abstract}
Most hereditary hemochromatosis ( $\mathrm{HH}$ ) patients are homozygous for the $\mathrm{C} 282 \mathrm{Y}$ mutation of the HFE gene. Nevertheless, penetrance of the disease is very variable. In some patients, penetrance can be mediated by concomitant mutations in other iron master genes. We evaluated the clinical impact of hepcidin (HAMP) and hemojuvelin mutations in a cohort of 100 Spanish patients homozygous for the $\mathrm{C} 282 \mathrm{Y}$ mutation of the HFE gene. HAMP and hemojuvelin mutations were evaluated in all patients by bidirectional direct cycle sequencing. Phenotype-genotype interactions were evaluated. A heterozygous mutation of the HAMP gene (G71D) was found in only one out of 100 cases. Following, we performed a study of several members of that family, and we observed several members had a digenic inheritance of the $\mathrm{C} 282 \mathrm{Y}$ mutation of the HFE gene and the G71D mutation of the HAMP gene. This mutation in the HAMP gene did not modify the phenotype of the
\end{abstract}

A. Altès $(\bowtie)$

Hematology Department, Althaia Foundation,

Flor de Lis 33,

08242 Manresa, Spain

e-mail: aaltesh@althaia.cat

A. Ruiz $\cdot$ A. Esteve

Laboratori Hospital de l'Esperit Sant,

Santa Coloma de Gramenet, Spain

J. Felez

ABS Canaletes,

Cerdanyola del Vallés, SPAIN

V. Bach • A. F. Remacha $\cdot$ M. P. Sardà • M. Baiget

Hematology and Genetics Departments, Hospital de Sant Pau,

Barcelona, Spain individuals who were homozygous for the C282Y mutation. One other patient presented a new polymorphism in the hemojuvelin gene, without consequences in iron load or clinical course of the disease. In conclusion, HAMP and hemojuvelin mutations are rare among Spanish $\mathrm{HH}$ patients, and their impact in this population is not significant.

Keywords HFE · Hepcidin · HAMP · Hemojuvelin •

Hemochromatosis · Iron metabolism

\section{Introduction}

Hereditary hemochromatosis $(\mathrm{HH})$ is characterised by impaired iron homeostasis, leading to an increase in intestinal iron absorption and excessive accumulation in tissues. If the disorder is not treated, the build-up of iron can cause tissue damage and may lead to cirrhosis, diabetes mellitus, arthropathy, cardiomyopathy, endocrine abnormalities and hepatocellular carcinoma [19]. The vast majority of cases of clinical hereditary hemochromatosis are associated with homozygosity for the C282Y HFE mutation (HH type 1) [9]. The penetrance of the disease is very variable. $\mathrm{HH}$ is generally considered a genetic condition with high prevalence but low morbidity $[1,5]$. Concomitant genetic and environmental factors may contribute to differential expression of C282Y homozygosity.

Other forms of hemochromatosis include type 2 or juvenile hemochromatosis, which can be caused by mutations in the HAMP, the gene coding for the iron regulatory peptide hepcidin [21] or in the hemojuvelin gene [18]. Type 3 is caused by mutations in the transferrin receptor 2 gene [8], and type 4 is described as an autosomal 
dominant iron overload that develops from a pathogenic mutation in the SLC40al gene (ferroportin disease) [16, 17, 20]. Some authors have described mutations in HAMP and HJV as genetic modifiers of the hemochromatosis phenotype in humans $[10,12,15]$. The objective of this study was to determine the impact of alterations in HAMP and HJV genes on the phenotype of homozygous patients for the C282Y mutation, in a clinically well-defined group of 100 Spanish $\mathrm{HH}$ probands [3].

\section{Materials and methods}

All patients selected for this study were referred to the hematologist for biochemical evidence of iron overload, with or without symptoms compatible with genetic hemochromatosis. Transferrin saturation and serum ferritin were measured at diagnosis by standard methods in samples obtained after an overnight fast. In those patients with a transferrin saturation index $\geq 55 \%$ or a serum ferritin level $\geq 400 \mu \mathrm{g} / \mathrm{L}$ on two occasions, HFE mutations were analysed using the LightCycler ${ }^{\circledR}$ 2.0 Real-Time Polymerase Chain Reaction (PCR) System [2] (Roche Diagnostics Gmbh, Mannheim, Germany). One hundred non-related homozygous C282Y patients were finally included in the study. All patients were diagnosed between 1985 and 2005. The total amount of iron removed was calculated as the number of phlebotomies (with $450 \mathrm{~mL}$ of blood drawn at each session) multiplied by 0.2 (the number of grams of iron removed per session). The hepatic iron concentration and the hepatic iron index were determined in 22 patients with evidence of liver disease [4]. All patients gave their written informed consent to participate in the study, in accordance with the protocol approved by the ethics committee at Sant Pau Hospital.

Definition of clinical complications To study the association between genetic polymorphisms and body iron stores, the median value of iron removed by phlebotomies and the median value of serum ferritin were used as threshold. To evaluate the clinical severity of the disease in each patient, we considered only two clinical complications classically related with hemochromatosis: liver damage and diabetes. Liver damage was diagnosed when aspartate transaminase and alanine aminotransferase enzymes were above normal limits at least twice at intervals of over 3 months or when there was histological evidence of liver fibrosis/cirrhosis. Patients considered diabetic were those receiving treatment for diabetes and those with a fasting plasma glucose test $\geq 126 \mathrm{mg} / \mathrm{dL}$ on two occasions. Alcohol consumption was assessed from patient history, and $>80 \mathrm{~g} /$ day of ethanol was considered excessive. Viral serology data for hepatitis B and $\mathrm{C}$ were available in all patients.
Mutational analysis

Genomic DNA was extracted from peripheral blood leukocytes using the FlexiGene DNA Kit (Qiagen, West Sussex, UK) in accordance with the manufacturer's instructions. Mutation detection was performed by PCR amplification of each of the three coding exons of the hepcidin gene (GeneBank No NM-021175) and the four coding exons of hemojuvelin gene (GeneBank no NM213653), including intron-exon junctions. The oligonucleotide primers used for PCR amplification and the PCR conditions of both genes are listed in Table 1. After purification with Qiaquick ${ }^{\circledR}$ PCR Purification Kit (Qiagen, West Sussex, UK), PCR products were subjected to bidirectional direct cycle sequencing using the BigDye ${ }^{\circledR}$ Terminator v1.1 Cycle Sequencing Kit (AppliedBiosystems, Warrington, UK) and an ABI PRISM ${ }^{\circledR}$ 3100-Avant Genetic Analyzer (Applied Biosystems). Sequencing primers were the same as those used for PCR amplification. The identified alterations were confirmed by additional sequencing of independently amplified PCR products from the same patients.

\section{Results}

Biochemical and clinical characteristics of the whole cohort have been described in detail elsewhere [3]. In summary, there were 73 men and 27 women, and the median age was 45 years (range 16-73). Fourteen patients consumed more than $80 \mathrm{~g} /$ day of alcohol, and three had a positive serology for hepatitis $\mathrm{C}$ virus. The median ferritin level for the whole group was $861.5 \mu \mathrm{g} / \mathrm{L}$ (range 17-10,000), and the median quantity of iron removed by phlebotomy was $4.25 \mathrm{~g}$ (range $0.5-20)$. The iron removed was $\geq 5 \mathrm{~g}$ in 43 patients. A liver biopsy was performed in 33 of 44 patients who presented with liver damage. Fibrosis-cirrhosis of the liver was finally diagnosed in 28 and liver cancer in four. Twenty-four patients had diabetes. Table 2 summarises the biochemical characteristics of this cohort.

\section{HAMP mutations}

The HAMP gene was normal in all but one case, a 61-year-old patient who presented with the G71D mutation in heterozygosity (patient III, Table 3). His transferrin saturation level was high $(82 \%)$, and he had the highest level of ferritin in the family $(2,500 \mu \mathrm{g} / \mathrm{L})$. He suffered liver disease, with an abnormal level of liver enzymes. A liver biopsy showed portal fibrosis without cirrhosis. About $9 \mathrm{~g}$ of iron was removed by phlebotomy. Three of the proband's four brothers were studied. The fourth had died some years earlier (patient II, Table 3). Two of the three living brothers 
Table 1 Oligonucleotides and conditions used for polymerase chain reaction

\begin{tabular}{|c|c|c|c|}
\hline Gene & Exon & Primer sequence $\left(5^{\prime}-3^{\prime}\right)$ & References \\
\hline \multirow[t]{6}{*}{ HAMP } & $1 \mathrm{~F}$ & GCC CCA TAA AAG CGA CTG TC & This work \\
\hline & $1 \mathrm{R}$ & CAT CCC TGC CCT GTA & This work \\
\hline & $2 \mathrm{~F}$ & CAG TCT CAG AGG TCC ACT & {$[22]$} \\
\hline & $2 \mathrm{R}$ & AAT GTG AGC AGG GAA CC & {$[22]$} \\
\hline & $3 \mathrm{~F}$ & TGC TCA CAT TCC CTT CCT TC & {$[14]$} \\
\hline & $3 R$ & CAA GAC CTA TGT TCT GGG GC & {$[14]$} \\
\hline \multirow[t]{14}{*}{ HJV } & $1 \mathrm{~F}$ & CCG TCA ACT CAG TAG CCA & {$[11]$} \\
\hline & $1 \mathrm{R}$ & CAT TTG GAC GAG AGA CAT C & {$[11]$} \\
\hline & $2 \mathrm{~F}$ & CCC CAA ATT CCA GTC TGT T & {$[11]$} \\
\hline & $2 \mathrm{R}$ & CTC ATT CAG GCT CAC ATG C & {$[11]$} \\
\hline & $3 \mathrm{~F}$ & CTC CGA TAG AGC AGA GGT C & {$[11]$} \\
\hline & $3 R$ & GGA GCA TTG CTG TTG AAT AG & {$[11]$} \\
\hline & $4 \mathrm{aF}$ & TAG TCC TGC ATC TCT ACT TGG & {$[13]$} \\
\hline & $4 \mathrm{aR}$ & TGC AGG TCC TGT TCA GCT G & {$[13]$} \\
\hline & $4 \mathrm{bF}$ & GCT CTC CTT CTC CAT CAA GG & {$[13]$} \\
\hline & $4 \mathrm{bR}$ & CTA GTA ATG GGA CTG ATG GTC CC & [13] Modified \\
\hline & $4 \mathrm{cF}$ & GTT CTG TGG CTT TGC ATT CAG & This work \\
\hline & $4 c \mathrm{R}$ & TCA TGT CTT CTG CTT TCA GCT C & This work \\
\hline & $4 \mathrm{dF}$ & TAA GTT TAG AGG TCA TGA AGG & This work \\
\hline & $4 \mathrm{dR}$ & GCC CTC TTT CAG TGG AGT G & This work \\
\hline
\end{tabular}

were homozygous for the $\mathrm{C} 282 \mathrm{Y}$ mutation of the HFE gene, and the other was heterozygous for this mutation. One of the YY brothers (I) was a 42-year-old man who had a positive serology for hepatitis $\mathrm{C}$ virus. He had a wild type HAMP gene. His transferrin saturation (TS) and ferritin levels were high $(93 \%$ and $1,400 \mu \mathrm{g} / \mathrm{L}$, respectively), liver enzymes were abnormal, and a liver biopsy showed portal fibrosis without cirrhosis. The total iron removed by phlebotomies in this patient was $10 \mathrm{~g}$. The second YY brother (IV) was a 68year-old man, with a wild-type HAMP gene. He had a longterm history of severe hematuria due to a bladder neoplasia at the time of diagnosis. For this reason, data about his serum ferritin and iron removed by phlebotomies were not suitable to evaluate aggressiveness of the hemochromatosis disease. The oldest brother (patient V) was a 71-year-old man who was heterozygous for the $\mathrm{C} 282 \mathrm{Y}$ mutation of the HFE gene. He had the same G71D mutation on the HAMP gene as the proband. Despite this digenic inheritance, his iron metabolism was normal, and he had not been submitted to any phlebotomy procedure.
Eleven offspring (five men, six women) were also evaluated. None of them were homozygous for the C282Y mutation. One individual was compound heterozygous for the $\mathrm{C} 282 \mathrm{Y}(\mathrm{CY})$ and the H63D mutations, eight were heterozygous for the $\mathrm{C} 282 \mathrm{Y}$ mutation, one was only heterozygous for the H63D mutation and only one individual had a normal HFE genotype. Five offspring were heterozygous for the G71D mutation of HAMP gene, three in combination with a $\mathrm{C} 282 \mathrm{Y}$ heterozygous mutation, one in combination with a heterozygous H63D mutation and one without any HFE mutation. No siblings showed features of iron overload. Iron deficiency was demonstrated in three cases, two of which were double heterozygous for C282Y and G71D mutations in HFE and HAMP genes, respectively (cases IIa and IIIc, Table 3).

Hemojuvelin mutations

Only one of the 100 patients studied had a non-described polymorphism in the HJV gene in heterozygosity. The
Table 2 Biochemical characteristics of the cohort of 100 homozygous $\mathrm{C} 282 \mathrm{Y}$ patients

${ }^{a} \mu \mathrm{Mol} / \mathrm{g}$ liver dry weight

${ }^{\mathrm{b}} \mu \mathrm{Mol} / \mathrm{g}$ liver dry weight)/age in years

\begin{tabular}{lccc}
\hline Parameter & Mean & Median & Range \\
\hline Transferrin saturation $(\%)$ & 82 & 84 & $30-161$ \\
Ferritin $(\mu \mathrm{g} / \mathrm{L})$ & 1,259 & 861 & $17-10,000$ \\
Iron removed $(\mathrm{g})$ & 5.5 & 4.2 & $0.5-20$ \\
Liver iron concentration $^{\mathrm{a}}(N=22)$ & 221 & 192 & $21-456$ \\
Hepatic iron index $^{\mathrm{b}}(N=22)$ & 4.6 & 4.5 & $0.43-8.75$ \\
\hline
\end{tabular}


Table 3 Clinical characteristics of a family which was homozygous for the C282Y mutation of the HFE gene and heterozygous for the G71D mutation of HAMP gene

\begin{tabular}{|c|c|c|c|c|c|c|c|c|c|c|c|}
\hline Case & $\begin{array}{l}\text { Age/ } \\
\text { sex }\end{array}$ & HFE & HAMP & $\begin{array}{l}\mathrm{HB} \\
(\mathrm{g} / \mathrm{L})\end{array}$ & MCV fl & $\begin{array}{l}\text { SAT } \\
(\%)\end{array}$ & $\begin{array}{l}\text { Ferritin } \\
(\mu \mathrm{g} / \mathrm{L})\end{array}$ & Glucose & $\begin{array}{l}\text { Liver } \\
\text { enzymes }\end{array}$ & $\begin{array}{l}\text { Iron } \\
\text { removed }\end{array}$ & Other \\
\hline I & $42 / \mathrm{M}$ & $\mathrm{YY} / \mathrm{HH}$ & GG & 172 & 93 & 93 & 1,400 & Normal & Abnormal & $10 \mathrm{~g}$ & $\mathrm{HCV}+$. Portal fibrosis \\
\hline Ia & $35 / \mathrm{F}$ & $\mathrm{CY} / \mathrm{HH}$ & GG & 135 & 90 & 30 & 32 & Normal & Normal & - & \\
\hline $\mathrm{Ib}$ & $37 / \mathrm{F}$ & $\mathrm{CY} / \mathrm{HH}$ & GG & 129 & 87 & 32 & 69 & Normal & Normal & - & \\
\hline Ic & $43 / \mathrm{F}$ & $\mathrm{CY} / \mathrm{HH}$ & GG & 140 & 86 & 21 & 68 & Normal & Normal & - & \\
\hline II & $-/ \mathrm{M}$ & $-1-$ & - & - & - & - & - & - & - & - & EXITUS \\
\hline IIa & $33 / \mathrm{M}$ & $\mathrm{CY} / \mathrm{HH}$ & GD & 137 & 83 & 18 & 7 & Normal & NORMAL & - & \\
\hline $\mathrm{IIb}$ & $40 / \mathrm{F}$ & $\mathrm{CY} / \mathrm{HH}$ & GG & 156 & 87 & 56 & 92 & Normal & Normal & - & \\
\hline III & $61 / \mathrm{M}$ & YY/HH & GD & 156 & 86 & 82 & 2,500 & Normal & Abnormal & $9 \mathrm{~g}$ & Portal fibrosis \\
\hline IIIa & $26 / \mathrm{M}$ & $\mathrm{CY} / \mathrm{HH}$ & GG & 154 & 101 & 32 & 57 & Normal & Normal & - & \\
\hline IIIb & $27 / M$ & $\mathrm{CY} / \mathrm{HH}$ & GD & 150 & 86 & 25 & 168 & NORMAL & Normal & - & \\
\hline IIIc & $36 / \mathrm{M}$ & $\mathrm{CY} / \mathrm{HH}$ & GD & 126 & 73 & 10 & 4 & Normal & Normal & - & \\
\hline IV & $68 / \mathrm{M}$ & YY/HH & GG & 150 & 76 & 73 & 359 & Abnormal & Normal & $3 \mathrm{~g}$ & Bladder neoplasia \\
\hline $\mathrm{V}$ & $71 / \mathrm{M}$ & $\mathrm{CY} / \mathrm{HH}$ & GD & 148 & 92 & 33 & 86 & Normal & NORMAL & - & \\
\hline $\mathrm{Va}$ & $30 / \mathrm{F}$ & $\mathrm{CC} / \mathrm{HH}$ & GD & 134 & 85 & 18 & 8 & Normal & Normal & - & \\
\hline $\mathrm{Vb}$ & $40 / \mathrm{M}$ & $\mathrm{CY} / \mathrm{HD}$ & GG & 154 & 86 & 34 & 126 & Normal & Normal & - & \\
\hline $\mathrm{Vc}$ & $45 / \mathrm{F}$ & $\mathrm{CC} / \mathrm{HD}$ & GD & 137 & 82 & 22 & 16 & Normal & Normal & - & \\
\hline
\end{tabular}

Cases I, II, III, IV and V were brothers. Cases Ia, Ib, Ic were sons of case I, etc.

patient was diagnosed with iron overload when he was 45 years old, after a routine medical exam. He was asymptomatic and had no familial history of hemochromatosis. He had a transferrin saturation index of $87 \%$ and a ferritin level of $454 \mu \mathrm{g} / \mathrm{L}$ at diagnosis. A genetic test confirmed the $\mathrm{C} 282 \mathrm{Y}$ homozygosity in the HFE gene. A Ser264Leu polymorphism was detected in exon 4 (TCG>TTG) of the hemojuvelin gene. $\mathrm{He}$ has since undergone venesections, and $4 \mathrm{~g}$ of iron had been extracted. He had not presented any complications associated with hemochromatosis, such as liver disease or diabetes. His family refused further genetic or medical exams.

\section{Discussion}

Our findings demonstrate that HAMP and HJV mutations are very infrequent among Spanish $\mathrm{HH}$ patients homozygous for the C282Y mutation of the HFE gene. This paucity of mutations/polymorphisms precluded the projected statistical comparisons of groups described in the "Materials and methods" section. We have therefore limited the report to a description of the patients with mutated genes and their families.

Only one polymorphism of each gene was detected in our cohort of 100 patients, and there was no clear impact on iron burden or clinical behavior of disease in either case. In the family carrying a G71D mutation in the HAMP gene, the proband patient suffered a severe iron overload, but a younger brother who did not have a mutation in the HAMP gene - although he was also C282Y homozygous - had an even higher level of iron removed (10 g). Moreover, three offspring were double heterozygous for $\mathrm{C} 282 \mathrm{Y}$ and G71D mutations in the HFE and HAMP genes, and none of the three had signs of iron overload. Nevertheless, two of the three, a 33-year-old man and a 36-year-old woman, suffered iron deficiency. The G71D mutation in the HAMP gene has been identified in France [10], Italy [6, 7] and UK [15]. Although this mutation modifies Gly71 which is located in between two pairs of cysteines with important structural roles, our findings, like those of previous authors [7], suggest it has only a minor, if any, effect on iron loading.

Our conclusion about the new single nucleotide polymorphism (SNP) in the hemojuvelin gene Ser264Leu is similar. The only patient we found with this polymorphism had a mild iron overload that was concordant with his C282Y homozygous condition. This SNP does not seem to influence the iron amount or clinical pattern of this individual with hemochromatosis. Our study population varied greatly. It ranged from patients with hepatic cirrhosis or liver cancer to asymptomatic individuals [3], illustrating the spectrum of the disorder. Previous studies have shown that HAMP and hemojuvelin mutations act as genetic modifiers in hemochromatosis [10, 12, 15]. Nevertheless, the very low frequency of these alterations in our patient cohort indicates a minor impact of these mutations in the penetrance of HH type 1 in Spanish patients. 
Acknowledgements This work was partially supported by grants from Fondo de Investigaciones Sanitarias (PI-04/1120) and Agencia d'Avaluació de Tecnología i Recerca Mèdica (005/29/2004).

\section{References}

1. Adams PC, Reboussin DM, Barton JC, McLaren CE, Eckfeldt JH, McLaren GD, Dawkins FW, Acton RT, Harris EL, Gordeuk VR, Leiendecker-Foster C, Speechley M, Snively BM, Holup JL, Thomson E, Sholinsky P, Hemochromatosis and Iron Overload Screening (HEIRS) Study Research Investigators (2005) Hemochromatosis and iron-overload screening in a racially diverse population. N Engl J Med 352:1769-1778 doi:10.1056/NEJMoa041534

2. Altes A, Ruiz A, Barceló MJ, Remacha AF, Puig T, Maya AJ, Castell C, Amate JM, Saz Z, Baiget M (2004) Prevalence of C282Y, H63D and S65C mutations of HFE gene in 1146 newborns from a region of Northern Spain. Genet Test 8:407410 doi:10.1089/gte.2004.8.407

3. Altes A, Ruiz A, Martinez C, Esteve A, Vela MD, Remacha AF, Sarda P, Bach V, Baiget M (2007) The relationship between iron overload and clinical characteristics in a Spanish cohort of 100 C282Y homozygous hemochromatosis patients. Ann Hematol 86:831-835 doi:10.1007/s00277-007-0336-0

4. Barry M, Sherlock SA (1971) Measurements of liver-iron concentration in needle-biopsy specimens. Lancet 1:100-103 doi:10.1016/S0140-6736(71)90838-5

5. Beutler E, Felitti VJ, Koziol JA, Ho NJ, Gelbart T (2002) Penetrance of 845-A (C282Y) HFE hereditary haemochromatosis mutations in USA. Lancet 359:211-218 doi:10.1016/S0140-6736 (02)07447-0

6. Biasiotto G, Belloli S, Ruggeri G, Zanella I, Gerardi G, Corrado M, Gobbi E, Albertini A, Arosio P (2003) Identification of new mutations of the HFE hepcidin, and transferring receptor 2 genes by denaturing HPLC analysis of individuals with biochemical indications of iron overload. Clin Chem 49:1981-1988 doi:10.1373/clinchem.2003.023440

7. Biasiotto G, Roetto A, Daraio F, Polotti A, Gerardi GM, Girelli D, Cremonesi L, Arosio P, Camaschella C (2004) Identification of new mutations of hepcidin and hemojuvelin in patients with HFE C282Y allele. Blood Cells Mol Dis 33:338-343 doi:10.1016/j. bcmd.2004.08.002

8. Camaschella C, Roetto A, Cali A, De Gobbi M, Garozzo G, Carella M, Majorano N, Totaro A, Gasparini P (2000) The gene TFR2 is mutated in a new type of haemochromatosis mapping to 7q22. Nat Genet 25:14-15 doi:10.1038/75534

9. Feder JN, Gnirke A, Thomas W, Tsuchihashi Z, Ruddy DA, Basava A, Dormishian F, Domingo R Jr, Ellis MC, Fullan A, Hinton LM, Jones NL, Kimmel BE, Kronmal GS, Lauer P, Lee VK, Loeb DB, Mapa FA, McClelland E, Meyer NC, Mintier GA, Moeller N, Moore T, Morikang E, Prass CE, Quintana L, Starnes SM, Schatzman RC, Brunke KJ, Drayna DT, Risch NJ, Bacon BR, Wolff RK (1996) A novel MHC class I-like gene is mutated in patients with hereditary haemochromatosis. Nat Genet 13:399408 doi:10.1038/ng0896-399
10. Jacolot S, Le Gac G, Scotet V, Quere I, Mura C, Ferec C (2004) HAMP as a modifier gene that increases the phenotypic expression of the HFE pC282Y homozygous genotype. Blood 103:2835-2840 doi:10.1182/blood-2003-10-3366

11. Lanzara C, Roetto A, Daraio F, Rivard S, Ficarella R, Simard H, Cox TM, Cazzola M, Piperno A, Gimenez-Roqueplo AP, Grammatico P, Bolina S, Gasparini P, Camaschella C (2004) Spectrum of hemojuvelin gene mutations in 1q-linked juvenile hemochromatosis. Blood 103:4317-4321 doi:10.1182/blood2004-01-0192

12. Le Gac G, Scotet V, Ka C, Gourlaouen I, Bryckaert L, Jacolot S, Mura C, Férec C (2004) The recently identified type 2A juvenile haemochromatosis gene (HJV), a second candidate modifier of the C282Y homozygous phenotype. Hum Mol Genet 13:1913-1918 doi:10.1093/hmg/ddh206

13. Lee PL, Beutler E, Rao SV, Barton JC (2004) Genetic abnormalities and juvenile hemochromatosis: mutations of the HJV gene encoding hemojuvelin. Blood 103:4669-4671 doi:10.1182/blood2004-01-0072

14. Majore S, Binni F, Ricerca BM, Brioli G, Grammatico P (2002) Absence of hepcidin gene mutations in 10 Italian patients with primary iron overload. Haematologica 87:221-222

15. Merryweather-Clarke AT, Cadet E, Bomford A, Capron D, Viprakasit V, Miller A, McHugh PJ, Chapman RW, Pointon JJ, Wimhurst VL, Livesey KJ, Tanphaichitr V, Rochette J, Robson KJ (2003) Digenic inheritance of mutations in HAMP and HFE results in different types of haemochromatosis. Hum Mol Genet 12:2241-2247 doi: $10.1093 / \mathrm{hmg} / \mathrm{ddg} 225$

16. Montosi G, Donovan A, Totaro A, Garuti C, Pignatti E, Cassanelli S, Trenor CC, Gasparini P, Andrews NC, Pietrangelo A (2001) Autosomal-dominant hemochromatosis is associated with a mutation in the ferroportin (SLC11A3) gene. J Clin Invest 108:619-623

17. Njajou OT, Vaessen N, Joosse M, Berghuis B, van Dongen JW, Breuning MH, Snijders PJ, Rutten WP, Sandkuijl LA, Oostra BA, vanDuijn CM, Heutink P (2001) A mutation in SLC11A3 is associated with autosomal dominant hemochromatosis. Nat Genet 28:213-214 doi:10.1038/90038

18. Papanikolaou G, Sauels ME, Ludwig EH, MacDonald MLE, Franchini PL, Dubé MP, Andres L, MacFarlane J, Sakellaropoulos N, Politou M, Nemeth E, Thompson J, Risler JK, Zaborowska C, Babakaiff R, Radomski CC, Pape TD, Davidas O, Christakis J, Brissot P, Lockitch G, Ganz T, Hayden MR, Goldberg YP (2004) Mutation in HFE2 cause iron overload in chromosome 1q-linked juvenile hemochromatosis. Nat Genet 36:77-82 doi:10.1038/ng 1274

19. Pietrangelo A (2004) Hereditary hemochromatosis - a new look at an old disease. N Engl J Med 350:2383-2397 doi:10.1056/NEJMra031573

20. Pietrangelo A (2004) The ferroportin disease. Blood Cells Mol Dis 32:131-138 doi:10.1016/j.bcmd.2003.08.003

21. Roetto A, Papanikolau G, Politou M, Alberti F, Girelli D, Christakis J, Loukopoulos D, Camaschella C (2003) Mutant antimicrobial peptide hepcidin is associated with severe juvenile hemochromatosis. Nat Genet 33:21-22 doi:10.1038/ng1053

22. Roetto A, Daraio F, Porporato P, Caruso R, Cox TM, Cazzola M, Gasparini P, Piperno A, Camaschella C (2004) Screening hepcidin for mutations in juvenile hemochromatosis: identification of a new mutation (C70R). Blood 103:2407-2409 doi:10.1182/blood-2003-10-3390 